\title{
ASTHMA CAUSED BY THE COMPLEX SALTS OF PLATINUM
}

\author{
BY \\ DONALD HUNTER, REGINALD MILTON and KENNETH M. A. PERRY \\ From the Department for Research in Industrial Medicine (Medical Research Council), The London Hospital
}

Platinum is a rare metal of the group which includes ruthenium, rhodium, palladium, osmium and iridium. Up to 1915 almost the whole of the world's platinum production came from alluvial deposits in Russia and Colombia. In these deposits the platinum occurs as native metal alloyed with small amounts of the other metals of the group and with iron. In more recent years other sources of the platinum metals have become available. The most important new source is the nickel-copper-iron sulphide ores of the Sudbury district of Ontario, Canada, which are worked primarily for their nickel and copper contents, but which yield in addition very important amounts of the platinum metals. A second new source is the sulphide-bearing norite of the Potgietersrust and Rustenburg districts of the Transvaal. In the Sudbury ores the platinum is present chiefly in combination with arsenic, and in the South African ores it is combined with sulphur. New alluvial deposits have also been developed in Alaska, Abyssinia and elsewhere.

Platinum and its alloys are manufactured into sheet and wire for use in jewellery, dentistry, and the chemical and electrical industries. These products are made chiefly by the usual metallurgical processes of melting, casting, forging, rolling, and wire drawing. Recently, however, the increased production of finely divided metal powders from complex platinum salts has led to increased handling of these salts in the precious metal industry.

Of the many and varied uses of platinum, attention is directed here more particularly to the use of the platinum salts and their aqueous solutions. The chemical industry handles considerable quantities of hexachloroplatinic acid, $\mathrm{H}_{2} \mathrm{PtCl}_{6}$, in the manufacture of platinum catalysts. The electroplating industry deposits platinum from aqueous solutions containing various platinum salts such as sodium hexahydroxy-platinate $\mathrm{Na}_{2} \mathrm{Pt}(\mathrm{OH})_{6}$, dinitrodiammino platinum $\left(\mathrm{Pt} 2 \mathrm{NH}_{3}\left(\mathrm{NO}_{2}\right)_{2}\right)$, and from phosphate solutions.

In photography use is made of a paper sensitized with a mixture of potassium chloroplatinite $\mathrm{K}_{2} \mathrm{PtCl}_{4}$, and ferric oxalate. Barium platino-cyanide $\mathrm{BaPt}(\mathrm{CN})_{4}$, is used in x-ray fluorescent screens. In opthalmology Duggen and Narravala (1941) described the use of platinum chloride for the tattooing of opacities in the cornea. Stenius (1941) used it as a histological method for staining the visual purple.

The literature of the toxicology and pharmacology of platinum and its salts is scanty. The first mention is made in 1827 when Gmélin described the effects of platinum chloride on animals. Prévost (1833) described its use in the treatment of epilepsy. Hofer (1840) advocated the use of platinum perchloride $\left(\mathrm{PtCl}_{4}\right)$ and sodium chloroplatinite $\left(\mathrm{Na}_{2} \mathrm{PtCl}_{6}\right)$ in the treatment of syphilis Pedler (1878) showed that platinum perchloride inactivates cobra venom in vitro, though Brunton and Fayrer (1878) pointed out that this was due to the formation of an insoluble compound with cobra poison and not to any action of platinum itself. The platinum perchloride is a chemical antidote and has no power to modify or prevent the action of the venom after its absorption into the blood. Carozzi (1934) gave an account of a chemist who developed discomfort, weakness, vertigo, and a remarkable acceleration of respiration and pulse rates about two hours after watching spongy platinum melted in refractory crucibles. White fumes which rose from the crucible, when heated with an oxyhydrogen flame, turned green. The platinum had been prepared from the residues of gold-bearing ores from Russia containing tellurium and other impurities.

Hofmeister (1882) described experiments showing the toxic effects of platinum ammine chlorides on frogs and rabbits. He showed that they first caused an increase of reflex sensitivity and even convulsions, and later fibrillary twitchings and a ' curare'-like paresis of the nerve endings in muscle. In the rabbits there were also epileptiform seizures and loss of consciousness. Hardman and Wright (1896) reported the death of a child aged 7 months who died five hours after the accidental administration of $8 \mathrm{gr}$. of potassium chloroplatinite. The child had previously been ill and a necropsy revealed a chronic ileo-colic intussusception. Chemical analysis detected the presence of platinum in the stomach and duodenum, but it was not present in any other organ. The immediate cause of death was considered to be cardiac syncope; but since the child was described as being in a feeble state of health, the case does not contribute much to present knowledge of the toxicology of platinum salts. The only reference to any toxic effect in adults is by Karasek and Karasek (1911) who in examining the workers in forty photographic studios in Chicago found eight cases of poisoning characterized by pronounced irritation of the throat and nasal passages, causing violent sneezing and coughing. There was also bronchial irritation causing respiratory difficulties so great that some individuals were entirely unable to use the paper containing potassium chloroplatinite Irritation of the skin causing cracking, bleeding and pain, was also observed

\section{Environmental Conditions in Platinum Refineries}

A full account is given of the metallurgy and methods of refining of the precious metals in the Imperial Institute reports on the mineral industry of the British Empire and foreign countries (1936); and in 1937 Johnson and Atkinson recorded the method used at the Acton refinery of the Mond Nickel Company (fig. 1). Whatever method is used in refining, the platinum is precipitated in the form of one of its complex salts, either ammonium chloro- 


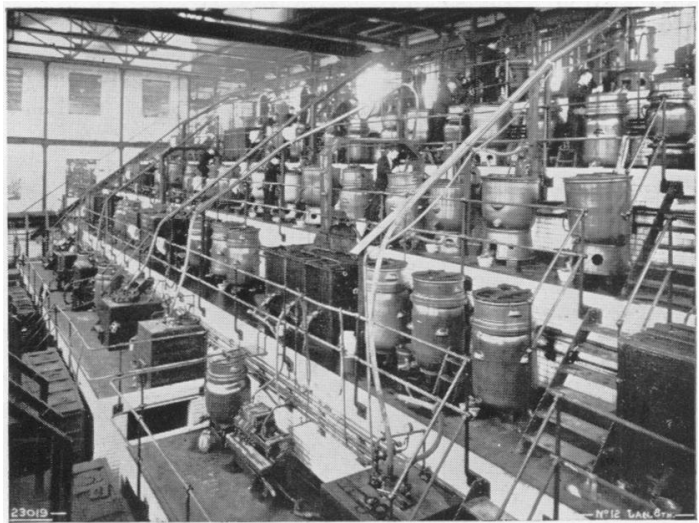

Fig. 1.-Wet-process department in Acton refinery of the Mond Nickel Company.

platinite $\left(\mathrm{NH}_{4}\right)_{2} \mathrm{PtCl}_{6}$, which is then ignited to produce platinum sponge, or sodium chloroplatinite $\mathrm{Na}_{2} \mathrm{PtCl}_{6} 6 \mathrm{H}_{2} \mathrm{O}$. The platinum sponge may then be sieved preparatory to further treatment. Sometimes the complex salts are handled in dry form and sometimes in a wet process. If they get into the atmosphere in the dry process it is in the form of dust, and in certain stages of the wet process they are thrown into the atmosphere in the form of droplets in a fine spray. The process of sieving the spongy platinum causes a dust of metallic platinum. The environmental conditions have been investigated in four refineries. At refinery $A$, a wet process involving sodium chloroplatinate was in operation; at refinery $\mathrm{B}$ a wet process caused the precipitation of ammonium chloroplatinate which was then dried; at refinery $\mathrm{C}$ dry ammonium chloroplatinate was handled, mostly under excellent exhaust ventilation, though where the salt was crushed this was less good, and at refinery D ammonium chloroplatinate, after precipitation, was ignited to form spongy platinum. The whole operation was carried out under exhaust ventilation, there being no anxiety about loss since the precious metals were recovered from the exhaust by an electro-static precipitator.

\section{Estimation of Platinum Salts and Metal in Low Concentrations}

The platinum content of the atmosphere at various points in these refineries was estimated. A volume of air was sucked through a particulate filter at a known flow-rate for a given time, usually during the whole of an operation. Air-borne concentrations of platinum dusts encountered in the process laboratories and factories may consist of soluble platinum salts, platinum metal or platinum metal mixed with other precious metals. If a mixture of precious metals was present, the following technique was employed.

Principle. The particulate filter with the mixture of precious metals was digested with aqua regia and brought into solution. Thallium nitrate was then added to form a thallium complex of the precious metals; this was rendered alkaline with ammonia, when the complexes of all the metals except platinum were dissolved and removed. The platinum complex was then dissolved off the paper with acid, and reduced to the platinous state by the addition of stannous chloride. Estimation of the orange colour of the platinous chloride by the colorimetric method of Snell and Snell (1936), gave a quantitative measurement of the concentration of platinum.

Technique. (i) The filter pad containing the dust sample was placed in a Kjeldahl flask and thoroughly digested with a few millilitres of aqua regia. The contents of the flask were then heated almost to dryness, care being taken not to char the digest. $20-30 \mathrm{ml}$. of water were added, together with a few drops of a 1 per cent. solution of thallium nitrate. After the formation of the thallium complex was complete, the solution was rendered alkaline with ammonium hydroxide and filtered. The filter paper was thoroughly washed with ammonia to remove all traces of the salts of extraneous metals.

(ii) The filter containing the platinum-thallium complex was then subjected to a further aqua regia digestion and carefully heated almost to dryness as before. A few millilitres of concentrated hydrochloric acid were added and the solution was boiled again to remove all traces of nitric acid. If necessary a second boiling with hydrochloric acid was carried out. To remove the hydrochloric acid the solution was evaporated to dryness and redissolved in water, and twice again evaporated to dryness.

(iii) The sample was then dissolved in a known volume of 3.3 per cent., by volume, solution of hydrochloric acid in distilled water and filtered. If this solution showed any yellow colour from the nitration of the filter paper, this colour was measured by the Hilger Spekker photo-electric colorimeter, and the reading subtracted from the reading obtained, later, after the development of the platinum colour. To $10 \mathrm{ml}$. of this solution (or an aliquot diluted to $10 \mathrm{ml}$. with the hydrochloric acid solution) was added $0.1 \mathrm{ml}$. of 40 per cent. stannous chloride $\left(\mathrm{SnCl}_{2}\right)$ in concentrated hydrochloric acid. The presence of platinum was shown by the development of a yellow-orange colour, which after 15 minutes development time was related to the amount of platinum in solution within a range of $10-500 \mu \mathrm{g}(\mu \mathrm{g}$ is $1 / 1000 \mathrm{mg}$.). If greater sensitivity was required, the solution after filtering was heated to dryness, and then dissolved in $5 \mathrm{ml}$. of the solution. In this way the method was made twice as sensitive as that already described. Even greater sensitivity may be obtained by dissolving the salt in $2.0 \mathrm{ml}$. of hydrochloric acid and taking readings on a sensitive photo-electric colorimeter with a mirror galvanometer. This micro-reading technique will give estimations as low as $0.5 \mu \mathrm{g}$ of platinum in solution. It is, however, so delicate that it is difficult to apply in the presence of large amounts of residue from filter paper digestion.

Calibration Curves. (Figs. 2 and 3.)

(a) Using Spekker colorimeter, with 10-ml. cup and dark blue filters.

$\begin{array}{rccc}\mu \mathrm{g} \mathrm{Pt} . & \text { Spk. reading } & \mu \mathrm{g} \mathrm{Pt} . & \text { Spk. reading } \\ 0 & 0 & 200 & 48 \\ 20 & 5 & 250 & 58 \\ 50 & 11 & 300 & 67 \\ 100 & 25 & 400 & 82 \\ 150 & 34 & 500 & 94\end{array}$

(b) Using micro-photometer with 2-ml. cups and violet figures.

$\begin{array}{cccc}\mu \mathrm{g} \mathrm{Pt} . & \begin{array}{c}\text { Galvanometer } \\ \text { difference }\end{array} & \mu \mathrm{g} \mathrm{Pt} . & \begin{array}{c}\text { Galvanometer } \\ \text { difference }\end{array} \\ 0.0 & 0.0 & 2.0 & 11 \cdot 2 \\ 0.5 & 3.5 & 2.5 & 13.0 \\ 1.0 & 6.5 & 3.0 & 14.6 \\ 1.5 & 9.2 & 3.5 & 15.8\end{array}$


Calibration Curve using Spekker Colorimeter with 10-ml. Cup and Dark Blue Filters.

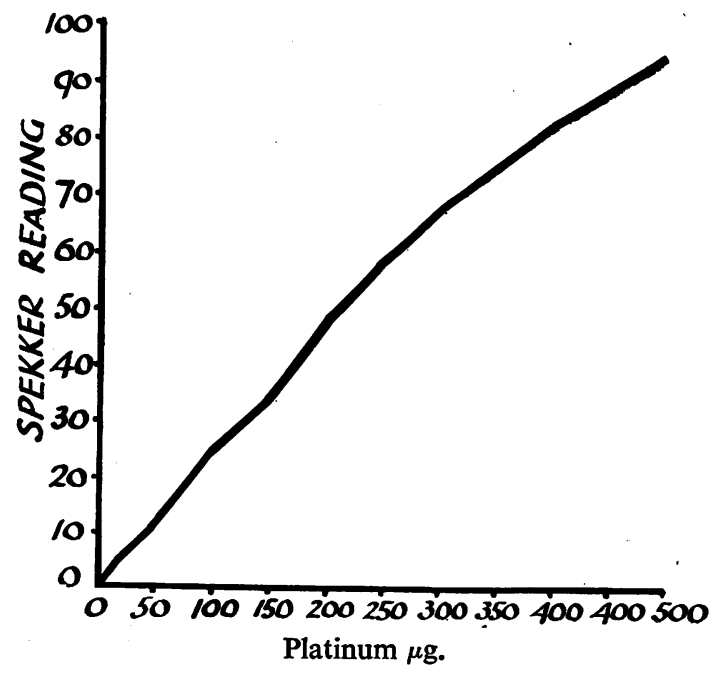

FIG. 2.

Calibration Curve using Micro-Photometer with 2-ml. Cups and Violet Filters.

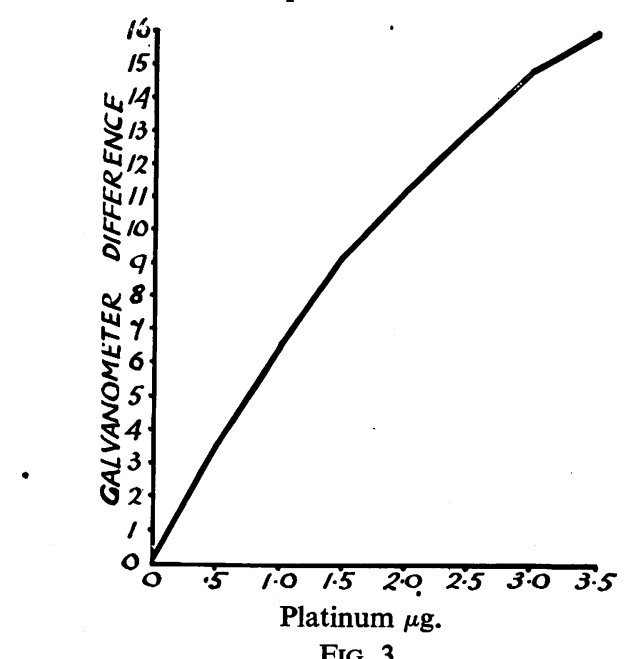

FIG. 3.

When the sample consisted only of soluble platinum salts the filter pad was digested with concentrated hydrochloric acid. The solution so obtained was diluted and filtered. It was then evaporated to dryness twice, after being dissolved in water, to remove excess hydrochloric acid. The platinum was then estimated by the colorimeter technique described in paragraph (iii) above.

When the sample contained metallic platinum, but no other precious metals, it was not necessary to carry out the process described in paragraph (i), but the estimation was made according to the technique described in paragraphs (ii) and (iii).

A. 1. Neutralizing platinum salts .. $\quad$.. $\quad 18 \mu \mathrm{g} / \mathrm{m}^{3}$

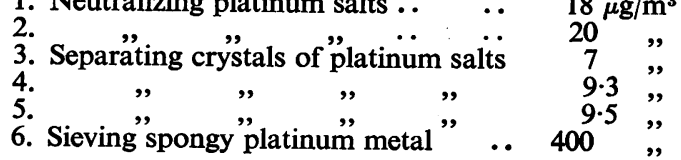

B. 1. Aqua regia treatment of crude platinum metals concentrate $\ldots \quad \ldots \quad 2.0 \mu \mathrm{g} / \mathrm{m}^{3}$

2. Precipitation and filtration of impure $\underset{\left(\mathrm{NH}_{4}\right)_{2} \mathrm{PtCl}_{6}}{0} \ldots$ iatinum

3. Dissolving impure platinum sponge

4. Precipitation and filtration of pure

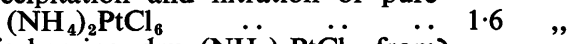

5. Discharging dry $\left(\mathrm{NH}_{4}\right)_{2} \mathrm{PtCl}_{6}$ from drying ovens $\quad \therefore \quad \ldots \quad \ldots$

6. Hand crushing and packing dry $\ddot{0} 50 \cdot 2$, $\left(\mathrm{NH}_{4}\right)_{2} \mathrm{PtCl}_{6}$ and $\left(\mathrm{Pd} 2 \mathrm{NH}_{3} \mathrm{Cl}_{2}\right)$ in ashless filter paper.

7. Precipitation and filtration of impure $\left(\mathrm{Pt} 2 \mathrm{NH}_{3} \mathrm{Cl}_{2}\right) \quad \ldots \quad \ldots \quad \quad .$.

8. Purification of rhodium 6.9 ,

9. Recovery of small amounts of precious metals from solutions by zinc reduction $\quad . . \quad \ldots \quad$..

10. Discharging residues from drying

C. 1. Crushing ammonium chloroplatinate $1700 \mu \mathrm{g} / \ddot{\mathrm{m}^{3}}$ 2. Atmosphere near reducing furnace .. 6 ,"

3. Aqua regia attack on platinum $\quad \cdots \quad 1.5$,

4. Sieving spongy platinum $\quad . . \quad \ldots 960$,,

D. 1. Aqua regia attack on platinum metal $1.0 \mu \mathrm{g} / \mathrm{m}^{3}$

3. Atmosphere near redücing bath fur-

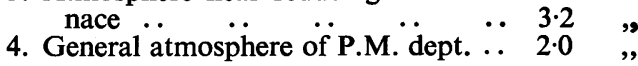

In refinery $B$, estimations were also made by spectrographic methods described by Fothergill, Withers and Clements (1945), and similar figures were obtained at the same sampling points.

\section{Investigation of Workers}

All the workers in these four refineries were interviewed. The history of any illness involving nasal or chest symptoms was obtained. Their occupational history was taken, and any family history of asthma was noted. They were examined clinically, and 15 in. $\times 12$ in. radiographs were taken of their chests. Full blood counts were obtained from all of them. An attempt was made at refinery $A$ to test their skin sensitivity by injecting intradermally 2 minims of a $1 / 10,000$ solution of sodium chloroplatinate. Unfortunately nearly half the workers refused this test, apparently owing to a fear of becoming sensitive to the salt. In the rest the intradermal test was unsatisfactory; and at refinery $\mathbf{B}$ a patch test had been previously tried and had given equivocal results. Skin tests were therefore not persisted with in refineries $B, C$ and $D$.

The age and sex of the employees in the four refineries were as follows:-

\begin{tabular}{|c|c|c|c|c|c|c|}
\hline Refinery & $\begin{array}{l}29 \text { and } \\
\text { under }\end{array}$ & $30-39$ & $40-49$ & $50-59$ & $\begin{array}{c}\text { Over } \\
60\end{array}$ & Tota \\
\hline $\begin{array}{l}\text { A male } . . \\
\text { female } . . \\
\text { B male } . . \\
\text { C male } . . \\
\text { female } . . \\
D \text { male } . .\end{array}$ & $\begin{array}{r}5 \\
10 \\
3 \\
1 \\
1\end{array}$ & $\begin{array}{r}4 \\
3 \\
19 \\
2 \\
2\end{array}$ & $\begin{array}{r}4 \\
1 \\
30 \\
2 \\
2\end{array}$ & $\begin{array}{r}\frac{6}{13} \\
\frac{1}{2}\end{array}$ & $\begin{array}{l}\frac{1}{2} \\
\text { - }\end{array}$ & $\begin{array}{r}20 \\
4 \\
74 \\
8 \\
1 \\
7\end{array}$ \\
\hline Total & 20 & 30 & 39 & 22 & 3 & 114 \\
\hline
\end{tabular}

They had worked in platinum refineries for the following number of years :- 


\begin{tabular}{c|r|r|r|r|r|r|r}
\hline $\begin{array}{c}\text { Re- } \\
\text { finery }\end{array}$ & $\begin{array}{r}4 \text { and } \\
\text { under }\end{array}$ & $5-9$ & $10-14$ & $15-19$ & $20-24$ & $\begin{array}{c}25 \text { and } \\
\text { over }\end{array}$ & Total \\
\hline A & 6 & 4 & 1 & 3 & 4 & 6 & 24 \\
B & 12 & 13 & 7 & 13 & 18 & 11 & 74 \\
C & 8 & 1 & -1 & - & -2 & -1 & 7 \\
D & 1 & 2 & 1 & - & 2 & 1 & 7 \\
\hline Total & 27 & 20 & 9 & 16 & 24 & 18 & 114 \\
\hline
\end{tabular}

Many of the men in these refineries suffered from a syndrome similar to that described by the Karaseks in Chicago in 1911. It started with repeated sneezing and was followed by profuse running of the nose with a watery mucous discharge. Then followed tightness of the chest, shortness of breath, cyanosis and a wheeze. These symptoms would persist so long as the men were in the factory and for about one hour after they left. The symptoms would then subside,'but often the man would wake in the early hours of the morning with a bout of coughing which might last half an hour. A compensatory polycythaemia was observed in one man seen during an attack. Some men also complained of a scaly erythematous dermatitis, and some of an urticarial rash. The following case histories are given as examples of the syndrome.

Case 1. R. C., aet. 58, research chemist, worked in refinery A from 1907 to 1924 (18 years). From the first year at this work he noticed a tightness of the chest with a wheeze when certain processes in the refinery which caused a spray were in operation. He noticed a tightening also in the muscles of the back and marked sneezing. There was a watering of the eyes and a dislike of light. He would go home and go straight to bed, and would wake up in the morning quite fit, only to repeat the same symptoms the next day. He was forced to leave the refinery in 1924 because the symptoms became so bad he could no longer carry on. Since then he has been perfectly well. On one occasion he returned to the refinery on business and immediately noticed a tightness of his chest, even though the process to which he was sensitive was not going on in the room. However, it was discovered that sodium chloroplatinate had been weighed out in the room about half an hour previously. There was no family history of asthma. He now showed no abnormal physical signs. His blood count was 4,160,000 red cells per c.c., haemoglobin 111 per cent. (photo-electric estimation of alkaline haematin 100 per cent., equivalent to $13.8 \mathrm{gm}$. haemoglobin per cent.), white cells 12,200 , polymorphs 61 per cent., small lymphocytes 6 per cent., large lymphocytes 27 per cent., large hyalines 6 per cent. Dr. D. Jenning. reported on an X-ray of his chest-old bilateral apical infection with fibrosis and drawing upward of both hila; emphysema of both bases.

Case 2. A. W., male, aet. 38, started work at the age of 15 in a chocolate manufacturing factory. He worked here for 6 months and then transferred to platinum refinery A. After six years on this work he noticed that when certain processes were in operation his nose started to run and he would start sneezing. This lasted for half an hour. The symptoms gradually got worse and after ten years he began to get tightness of his chest, shortness of breath, wheeze and cough, but he produced no sputum. He never had an attack at home. The attacks gradually got more frequent and more severe, and two months before he was interviewed he was moved to the 'other precious metals' department. Since this move he has not had a further attack. He had had no previous illness, and there was no family history of asthma. On examination no abnormal physical signs were found, except that when he painted a 3 per cent. solution of sodium chloroplatinate on his forearm a large wheal appeared. His blood count showed 5,120,000 red cells, 100 per cent. haemoglobin (photo-electric estimation), 11,200 white cells, 50 per cent. polymorphs, 41 per cent. lymphocytes, 3.5 per cent. eosinophils, 5.5 per cent monocytes. X-rays of his chest showed emphysema.

Case 3. E. V. N., chest, assistant manager of wet process at refinery $\mathrm{B}$, aet. 28 , had worked for five years in the laboratory and for $2 \frac{1}{2}$ years as assistant manager of the wet process. Immediately he started on the process he became aware that if he entered the room where ammonium chloroplatinate was dried his nose started to run, producing perfectly clear fluid. He would soak three handkerchiefs in an hour. He would develop severe sneezing attacks and some irritation of his eyes. After he had been there three months these symptoms were followed by tightness of the chest which would last for half an hour, and wheezing which lasted 5 hours. He would be awakened in the early hours of the morning with a cough which might last an hour, but the following day he would be quite fit. He had had no previous illness, and there was no family history of asthma. He entered the drying-room on the day he was interviewed and was observed in an attack. He was cyanosed, dyspnoeic and had an audible wheeze. His respiration rate was 34 . He had no clubbing of his fingers. His chest moved evenly, was hyper-resonant with normal air entry but many sibilant rhonchi throughout. There were no other abnormal physical signs. His blood count showed $6,350,000$ red cells, 130 per cent. haemoglobin (photo-electric estimation), 8200 white cells, 60 per cent. polymorphs, 30 per cent. lymphocytes, 5 per cent. eosinophils, 1 per cent. basophils and 4 per cent. monocytes. X-ray of his chest revealed no abnormality. During the attack he was given 10 minims of $1 / 1000$ adrenalin intramuscularly, but it did not produce any relief of the symptoms, though it raised the pulse rate from 80 to 120 .

Case 4 L. J., aet. 36, process hand, worked 7 years at a chemical plant and then for 14 years at platinum refinery $\mathrm{B}$ on the wet process and in the 'other precious metals department. During the past 3 years he had had attacks of running nose, sneezing, shortness of breath, tightness of the chest, wheeze and cough. He was frequently awakened by attacks of coughing at 2 a.m., and had had such an attack every night for the three months previous to his sick-leave which had lasted 3 weeks at the time of interview. He had never had any attacks while away from the works. He was moved to the time office, but still got some attacks, and was therefore transferred to another department where he would not be exposed to the salts of platinum. He had had pleurisy at the age of 8 , and had his tonsils removed 1 year previously because of his asthma. There was no family history of asthma. When examined he had not been at the refinery for three weeks, so he appeared a healthy man and showed no abnormal physical signs. His blood count showed 4,760,000 red cells, 104 per cent. haemoglobin (photo-electric estimation), 7450 white cells, 57 per cent. polymorphs, 1.5 per cent. eosinophils, $39 \cdot 5$ per cent. lymphocytes and 2 per cent. monocytes. Dr. M. H. Jupe reported on an X-ray of his chest as follows:- "There are a few scattered calcified nodules over the lung fields. The hilar shadows are well seen, but not excessive.'

Case 5. M. D., female, aet. 20, had worked as a press operator before entering platinum refinery $\mathrm{C}$; 3 months before her interview she was observed sieving spongy platinum without exhaust ventilation or mask, and was seen to be without any symptoms. She said that when she handled the dry complex salt her eyes and nose would run, and she sneezed continuously. She experienced some tightness of the chest the same evening, but this never woke her at night. She had never been ill, and had no family history of asthma. On examina- 
tion she had no abnormal physical signs. Her blood count showed $4,500,000$ red cells, 98 per cent. haemoglobin (photo-electric estimaton), 12,000 white cells, 58 per cent. polymorphs, 2 per cent. eosinophils, 34 per cent. lymphocytes, 6 per cent. monocytes. X-ray of her chest revealed no abnormality.

Case 6. A. A., chemist, aet 33, for past 4 years had been in charge of platinum refinery $D$. For 12 years before that he had been an analytical chemist. He had no symptoms except when he treated the filtrates with granulated zinc; this caused effervescence and droplets containing complex salts to be thrown into the atmosphere Then his nose ran and he sneezed. This might last for half an hour. He had no tightness of his chest, shortness of breath, cough or wheeze. He had had scarlet fever as a child, but there was no family history of asthma. On examination, apart from a very mild degree of funnel chest, he had no abnormal physical signs. His blood count showed 5,950,000 red cells, 118 per cent. haemoglobin (photo-electric estimation), 7000 white cells, 60 per cent. polymorphs, 36 per cent. lymphocytes, 1 per cent. eosinophils, and 3 per cent. monocytes.

Analysis of the occupation of the workers who complained of these symptoms and of the circumstances in which they occurred, produced conclusive evidence that the complex salts of platinum are the cause of the syndrome. The sieving of spongy platinum produces a much higher concentration of platinum in the atmosphere than the processes involving the complex salts. Workers have been observed sitting over this process without exhaust ventilation and without wearing masks; yet in no instance has asthma been found to arise among workers while engaged on this sieving. In two instances in refinery $\mathbf{A}$ and in three instances in refinery $\mathbf{B}$, workers who complained of asthma were removed from the platinum refining department to the 'other precious metals' department, where they handled principally ruthenium and rhodium without recurrence of the symptoms. The incidence was highest in those in contact with the complex salts in their dry form, but did occur also in those engaged on certain parts of the wet processes where droplets of the complex salts were thrown into the atmosphere. Maintenance men and men engaged on packing the complex salts stressed the fact that the dust immediately produced the symptoms described. In refinery $\mathrm{C}$ the symptoms were most severe where the salt was crushed, and at this point the complex salt concentration in the atmosphere was exceptionally high. It was interesting that the authorities at refineries $\mathrm{A}, \mathrm{B}$ and $\mathrm{C}$ were well aware that the syndrome had been occurring in their refineries for many years, yet those at refinery $D$ had never heard of it. On investigation the explanation was evident. At refinery $\mathrm{D}$ the ammonium complex salt was precipitated under exhaust ventilation, and then ignited to form spongy platinum, again with exhaust ventilation. Loss of the precious metal was not considered since it was trapped from the exhaust and recovered by an electro-static precipitator. There was thus no dust and no spray. There was, however, in this refinery, a process in which the filtrates were treated with granulated zinc, and there was a fine spray and no exhaust ventilation. The men were only in contact with the process for a few minutes at a time, and while none complained of shortness of breath, tightness of the chest or wheeze, 5 out of 7 said they noticed sneezing and running of the nose of short duration.

Analysis of occupation and symptoms showed that out of 91 men in contact with the complex salts of platinum, 52 have the asthmatic syndrome to some degree. The following table (Table 1)

TABLE 1

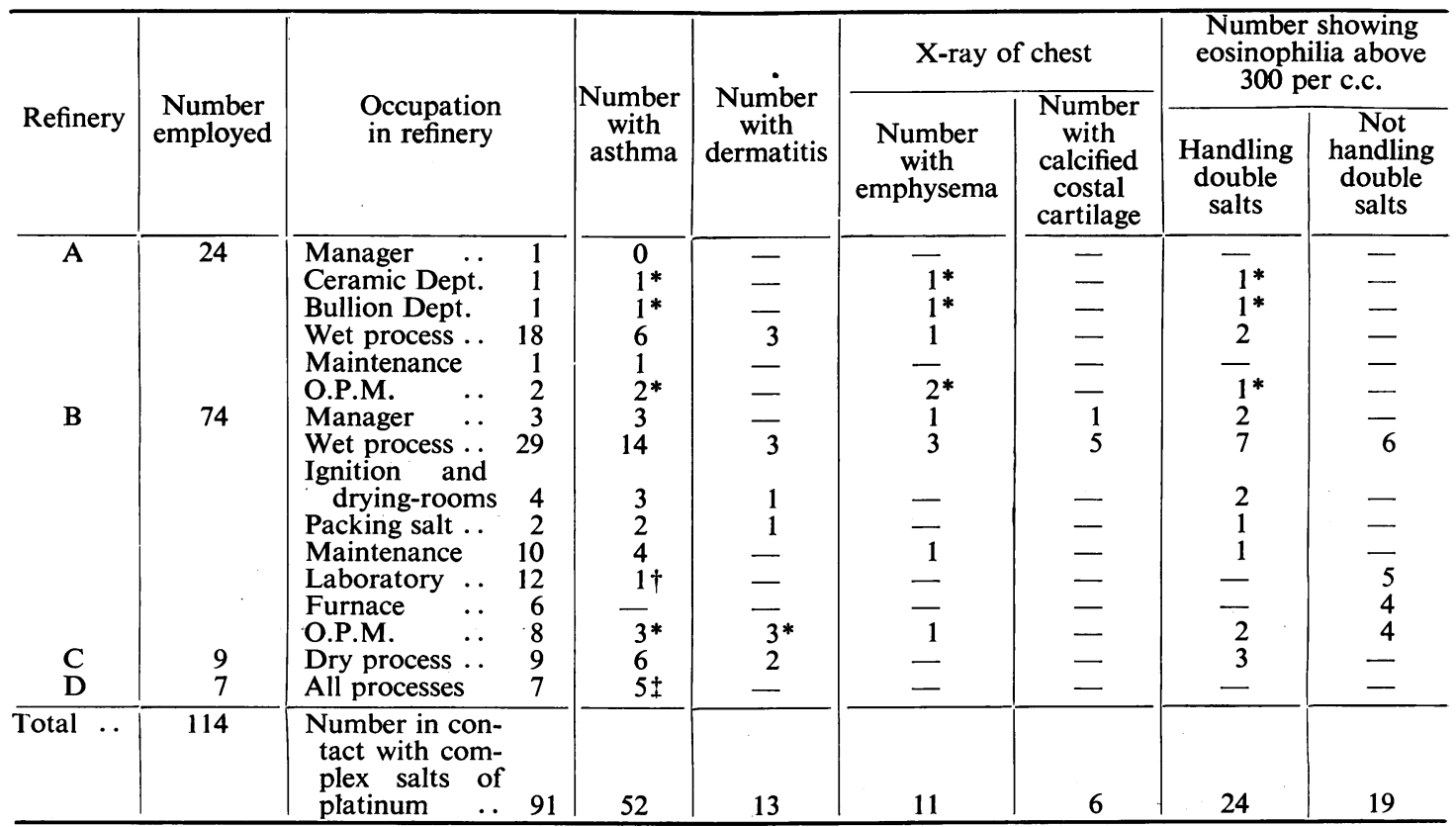

* Developed syndrome on wet process and moved to another department with complete relief.

$\dagger$ Handles complex salts of platinum.

$\ddagger$ Mild symptoms of running nose and sneezing when on process producing spray. 
gives the data of this analysis, as well as information on radiographic evidence of emphysema and calcification of the costal cartilages, and the numbers of workers with a total eosinophil count in the blood above 300 per c.c.

Of the men examined, 13 had suffered from skin lesions: these were mostly of a scaly erythematous type, though some were urticarial. They were confined to the parts of the body exposed either to dust or spray, involving principally the hands and forearms, but in the more severe cases the face and neck were also involved. The condition was not materially different from that which might be found in any chemical factory and diagnosed under the general heading, 'industrial dermatitis.' One of the workers at refinery $\mathbf{A}$ was so sensitive that on painting a 3 per cent. solution of sodium chloroplatinate on his arm a well marked wheal appeared within two minutes. Skin tests, which were carried out in refinery $\mathbf{A}$ by injecting intradermally 2 minims of a $1 / 10,000$ solution of sodium chloroplatinate, gave little information. The results are shown in Table 2.

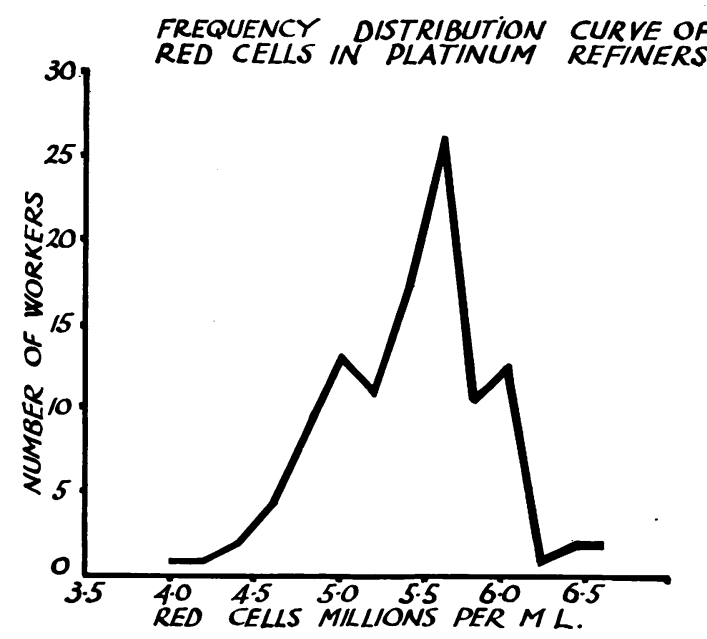

FIG. 4.

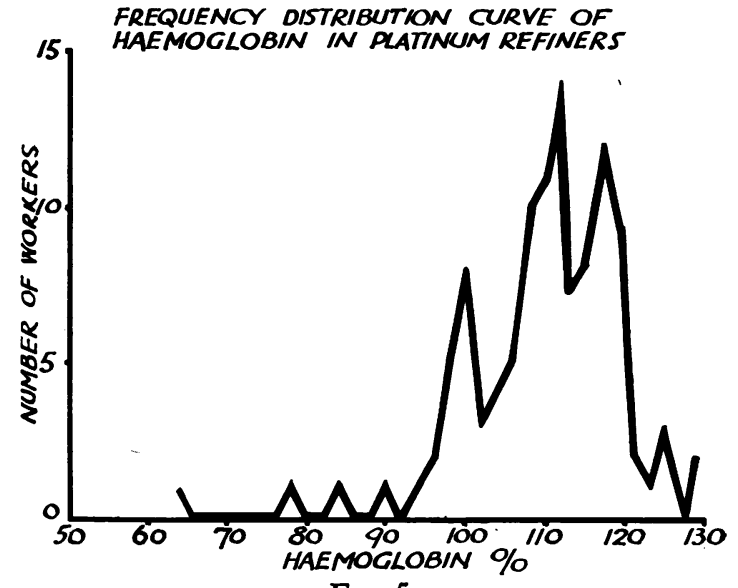

FIG. 5.

FREQUENCY DISTRIBUTION CURVE OF WHITE CELLS IN PLATINUM REFINERS

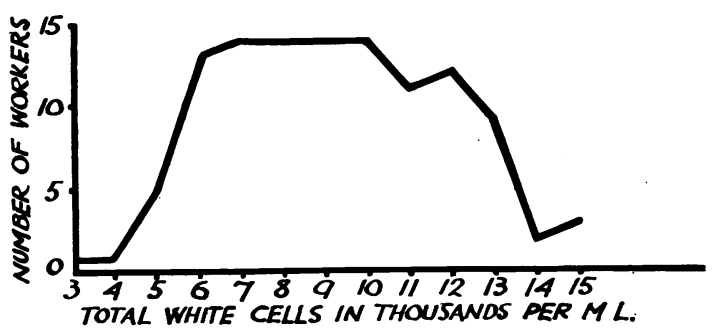

FIG. 6.

Examination of the $\mathrm{x}$-ray films of the chest of this group of workers revealed nothing outstanding. It would be expected that emphysema would develop in those who had repeated attacks of asthma, and the incidence of radiological signs of emphysema and catarrhal bronchitis is high. Another observation was that in 6 instances there was gross calcification of the costal cartilages. This incidence is probably higher than would be found in a similar group of the population at large. Evidence of

TABLE 2

\begin{tabular}{|c|c|c|c|c|c|c|}
\hline \multirow{2}{*}{ Case No. } & \multirow{2}{*}{ Sex } & \multirow{2}{*}{ Age } & \multirow{2}{*}{ Symptoms } & \multicolumn{3}{|c|}{ Skin test results } \\
\hline & & & & Immediate & 24 hours & 48 hours \\
\hline $\begin{array}{l}1036 \\
1037 \\
1038 \\
1039 \\
1042 \\
1043 \\
1044 \\
1045 \\
1050 \\
1051 \\
1052 \\
1053 \\
1054 \\
1055 \\
1056 \\
1058\end{array}$ & $\begin{array}{l}\mathbf{M} \\
\mathbf{M} \\
\mathbf{M} \\
\mathbf{M} \\
\mathbf{M} \\
\mathbf{M} \\
\mathbf{M} \\
\mathbf{M} \\
\mathbf{M} \\
\mathbf{M} \\
\mathbf{M} \\
\mathbf{M} \\
\mathbf{M} \\
\mathbf{F} \\
\mathbf{F} \\
\mathbf{F}\end{array}$ & $\begin{array}{l}38 \\
29 \\
64 \\
54 \\
31 \\
35 \\
56 \\
45 \\
51 \\
49 \\
56 \\
55 \\
43 \\
48 \\
33 \\
39\end{array}$ & $\begin{array}{c}\text { Asthma } \\
\text { Nil } \\
\text { ", } \\
\text { Running of nose } \\
\text { Asthma } \\
\text { Dermatitis } \\
\text { Nil } \\
\text { Asthma and dermatitis } \\
\text { Asthma } \\
, \Longrightarrow \\
, \Longrightarrow \\
\text { Nil }\end{array}$ & $\begin{array}{c}\text { 3-mm. wheal } \\
\text { Nil } \\
\text { 5-mm. wheal. } \\
\text { Nil } \\
\text { ", } \\
\text { ", wheal } \\
\text { 15-mil } \\
\text {," } \\
\text {," } \\
\text {,"wheal } \\
\text { 5-mil }\end{array}$ & $\begin{array}{c}\text { Nil } \\
, " \\
\text { ", } \\
\text { 2-5-mm. wheal } \\
\text { 3-mm. wheal } \\
\text { Nil } \\
\text { 6-mm. wheal } \\
\text { Nil } \\
\text { ". wheal } \\
\text { 4-mm. wheal } \\
\text { 3-mm. wheal } \\
\text { 4-mm. wheal } \\
\text { Nil } \\
\text {," }\end{array}$ & $\begin{array}{c}\text { Nil } \\
\text { ", } \\
, \\
, \\
\text { ", } \\
\text { 6-mm.,wheal } \\
\text { Nil } \\
\text { ", } \\
\text { ", } \\
\text { ", }\end{array}$ \\
\hline
\end{tabular}




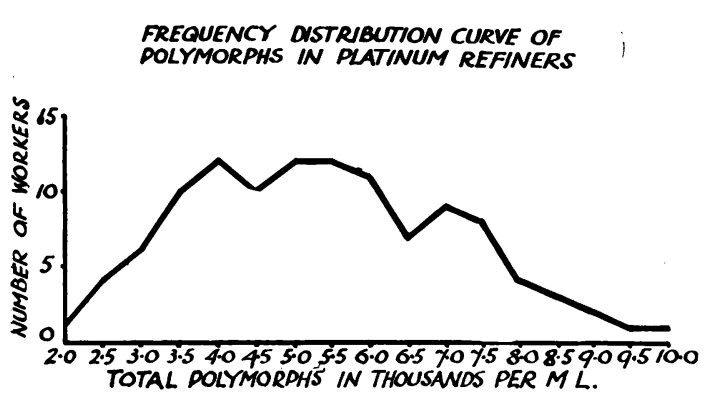

FIG. 7.

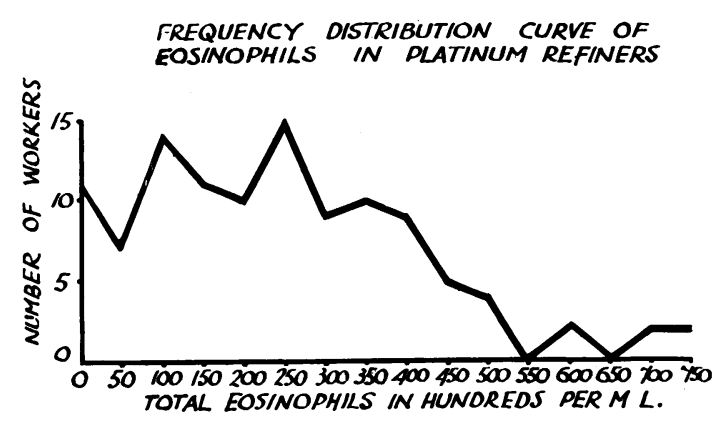

FIG. 8.

arrested or calcified pulmonary tuberculosis was found in 5 instances, and active disease was present in one instance.

The blood counts revealed normal red cell counts and haemoglobin levels, except for case 3 who was observed in an attack, and had a marked compensatory polycythaemia. There is, however, a tendency towards a polymorphonuclear leucocytosis, but this is probably of no significance since the range of variation in white cell counts in the industrial population during the war has been wide. The eosinophil counts tend to be high, but none are extremely high. Frequency distribution curves have been drawn from all these figures.

\section{Prevention and Treatment}

Prevention of this syndrome can be achieved by not allowing the complex salts of platinum to reach the atmosphere of the workshop, either in the form of dust or spray. This can be achieved by exhaust ventilation. Dust is worse than spray; therefore, unless it is necessary for technical reasons, it is advisable that the double salts of platinum should not be dried. Masks give some protection, but since they introduce the human factor, they are unsatisfactory.

Treatment consists of removal from exposure to the dust or spray. It is advisable to wash away the salts from the nose with water. Fresh air relieves the symptoms more quickly than anything else. Oxygen may help to relieve symptoms; and Adrenalin injected intramuscularly may help to relieve a severe attack.

\section{Summary}

A syndrome consisting of running of the nose, sneezing, tightness of the chest, shortness of breath, cyanosis, wheezing and cough is described.

This syndrome occurred in 52 out of 91 men exposed to the dust or spray of the complex salts of platinum.

Thirteen men complained of dermatitis.

These syndromes did not arise in men exposed to much higher concentrations of metallic platinum in the atmosphere, or to men exposed to the complex salts of the other precious metals, including palladium.

Prevention is by exhaust ventilation.

\section{Acknowledgments}

We should like to express our gratitude to the precious metal refining companies and their managers for their courtesy in allowing us to carry out this investigation, and for their help during it.

We are indebted to Dr. James Maxwell, Mr. A Parker Hague and Dr. A. J. Amor for drawing our attention to the existence of the condition, to Dr. M. H. Jupe and Dr. D. Jennings for reporting on the radiographs, to Mr. H. J. Ferrier for taking them, and to Mr. W. D. Duffield and Mr. L. Hoskins for technical help.

\section{REFERENCES}

Brunton, T. L. and Fayrer, J. (1878). Proc. roy. Soc., 27, 465.

Brunton, T. L., and Fayrer, J. (1878). Proc. roy. Soc., 27, 465.

Carozzi, L. (1934). Occupation and Health, Geneva, 2, 669. 20.419 Fothergill, S. J. R., Withers, D. F. W., and Clements, F. S. (1945) Brit. J. industr. Med., 2, 99.

Gmélin, C. G. (1827). Edinh. J. med. Sci., 3, 324

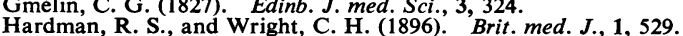

Hardman, R. S., and Wright, C. H. (1896).

Hofmeister, F. (1882). Arch. exper. Path., 16, 393.

Imperial Institute, Mineral Resources Dept. Reports on the Mineral Industry of British Empire and Foreign Countries (1936). Industry of British Empire

Johnson, C., and Atkinson, R. H. (1937). Trans. Instit. chem. Eng., 15,131 .

Karasek, S. R., and Karasek, M. (1911). Rep. Ill. State Commission Occ. Dis. p. 97.

Pedler, A. (1878). p. Proc. roy. Soc., 27, 17.

Prévost, J. L. (1833). Ann. Chem. 5 , 231.

Snell, F. D., and Snell, C. T. (1936). Colorimetric Methods of Stenius, S. (1941). Acta phys. scand., 1, 380. 